\title{
Hz. Peygamber (sav)'in Kurduğu Devlette Milli İrade
}

\author{
National Willpower in the State Founded by the Prophet (pbuh)
}

\author{
Dr. Öğr. Üyesi Eyüp KURT ${ }^{\text {D } 1}$
}

\begin{abstract}
$\ddot{\mathbf{O} z}$
Risalet'in Mekke döneminde Allah Resulü'nün (sav) getirdiği dini benimseyen az sayıda insan olmuştur. Aynı zamanda ne kendisinin ne de müminlerin güvenliğini sağlayacak bir üst otorite de tesis edilememiştir. Ayrıca Hz. Peygamber'in tevhit inancını merkeze alan davasıyla putperestliği esas alan Mekke'deki kurulu düzen taban tabana zıt olduğundan, Dâru'n-Nedve riyaseti Allah Resulü (sav)'nün nübüvvet görevini bu şehirde sürdürmesine imkân vermemiştir. $\mathrm{Bu}$ şartlarda ilahi görevin sürdürülebilmesi mümkün olmadığından farklı alternatifler üzerinde yoğunlaşan Hz. Peygamber, başka bir arayış için yola çıkan Medineli Hazreclilerle Akabe'de karşılaşmıştır. Yapılan müzakereler sonucunda taraflar beklentilerini gerçekleştirmek üzere karşılıklı anlaşmışlardır. Her iki tarafın da beklentilerini karşılamaya yönelik olarak bir taraftan üst bir otorite tesis edilirken aynı zamanda yeni değerler ile de donatılmış yeni bir toplum oluşturulmuştur. Medine Vesikası ile çerçevesi belirlenen üst otorite, sadece Ensar ve Muhacirleri değil aynı zamanda şehirde yaşayan Yahudileri de bir araya getirmeyi başarmıştır. Böylece sadece kurucu unsur durumundaki Ensar ve Muhacirlerin talepleri yerine getirilmekle yetinilmeyip aynı zamanda şehirde yaşayan diğer din mensupları da sisteme dâhil edilerek onların da bahsi geçen birlik beraberlikten istifade etmelerine imkân verilmiştir. Bütün bu gelişmelerin başarılmasının hareket noktası, tarafların millet iradelerinin bir noktada uzlaşmaları olmuştur. Bahsi geçen dinamiklerin etkili olduğu bu oluşum hem Yesrib şehrini Medine'ye dönüştürdüğ̈ gibi, sadece Hicaz veya Arap Yarımadası'nda değil aynı zamanda bütün dünyanın içinde bulunduğu buhrandan kurtulması için yeni bir soluk olmayı da başarmıştır.
\end{abstract}

Anahtar Kelimeler: Hz. Peygamber, milli irade, Mekke, Medine, İslamiyet

Makale Türü: Araştırma

\begin{abstract}
In the Makkah period of the prophet, there were a few people who adopted the religion brought by the Messenger of Allah. At the same time, a higher authority could not be established that would ensure the safety of neither himself nor the believers. In addition, since the established order in Mecca, which is based on idolatry with the Prophet's cause centered on the beliefof oneness, Daru'n-Nedve did not allow the Prophet to continue his duty of prophethood in this city. Since it is not possible to continue the divine duty under these conditions, the Prophet met in Aqaba with the people of Hazrac from Medina, who set out for another quest. As a result of the negotiations, the parties have mutually agreed ta realize their expecttations. While a higher authority was established in order to meet the expectations of both parties, a new society was created, which was also equipped with new valuees. The higher authority, whose framework was determined with the Medina Document, succeeded in bringing together not only the Ansars and Immigrant, but also the Jews in the city. Thus, not only the demands of the Ensars and Immigrants, who were the founding elements, were fulfilled, but also the members of other religions living in the city were also included in the system, allowing them to benefit from the mentioned union. The starting point fort he achivement of all these developments has been the agreement of the nation's will at some point. This formation, which was influenced buy the aforementioned Dynamics, not only transformed the city of
\end{abstract}

\footnotetext{
${ }^{1}$ Afyon Kocatepe Üniversitesi, İslami İlimler Fakültesi, ekurt@aku.edu.tr.

Atıf için (to cite): Kurt, E. (2020). Hz. Peygamber (sav)'in kurduğu devlette milli irade. Afyon Kocatepe Üniversitesi Sosyal Bilimler Dergisi, 22(TBMM'nin 100. Yı1ı ve Millî İrade Özel Sayısı), 133-147.
} 
Yathrib into Medina, but also managed to become a new breath not only in the Hejaz or the Arabian Peninsula, but also fort he whole word to get rid of the crisis.

Keywords: The Prophet, Islam, national willpower, Mecca, Medina

Paper Type: Research

\section{Giriș}

Cahiliye döneminde Hicaz bölgesinde ikamet eden Araplar, bedevî ve hadarî olarak yaşıorlardı. Çölde göçebe olarak yaşayan bedevilerle Mekke, Medine ve Taif gibi şehirlerde yaşayan hadarî Araplar, hayatlarını kabile sistemine göre sürdürüyorlardı. Şeyh adı verilen ve kabilenin önde gelenleri tarafından belirlenen kabile reisi tek başına mutlak bir yönetim gücüne sahip değildi. Kabile, oligarşik bir yönetim yapısına sahip olduğundan, önde gelenlerin kanaati yeterli görülür, çoğunluğun tercihi dikkate alınmazdı. Diğer bir ifadeyle kabilede bireyin tercihinden ziyade şeyh tarafından temsil edilen kabilenin tüzel kişiliği çok daha ön plandaydı. Varlık sebebi mağduriyetleri gidermek olan Mekke'de kurulu Hilfu'l-Fudûl gibi cemiyetlere katılım sınırlı sayıda idi. Hâlbuki bu cemiyet, bir taraftan mazlumu zalimin zulmünden korumaya çalışırken, bir taraftan da karşılıklı güvene dayanan ticareti geliştirmeyi ve ayet-i kerimede "güvenli belde" ${ }^{2}$ olarak nitelendirilen Mekke'nin saygınlığının zedelenmesini engellemeye çalışıyordu. Geçimini genellikle ticaretle elde eden bu toplumun yönetimi elinde bulunduran kesimi, biraz da asabiyet kaygısıyla bu tür kamu kuruluşlarına çok da sempatiyle yaklaşmamışlardı. En önemli itici gücü asabiyet olan kabile rekabetleri, sürdürülebilir bir sistem inşa etme yerine, giderek daha da küçülen yapıların ortaya çıkmasına sebep oluyordu. Bu durum; kan, gözyaşı, nefret gibi ayrışmayı körükleyen duyguların daha da artışına sebep olmaktaydı. Bu tür negatif duygular ile çepeçevre kuşatılan kitleler için hayat çekilmez hale gelmekteydi. İşte böyle bir psikoloji içinde kıvranan iki kardeş kabile Evs ile Hazrec, özgüvenlerini tamamen kaybetmiş durumda, onların ellerinden tutup ayağa kaldıracak üçüncü bir kabile arayışı için yollara düşmüşlerdi. Bu beklentiyle yola çıkan Hazrecli 6 kişi, Akabe'de Hz. Peygamber (sav) ile karşılaşacak ve aradıklarının daha da fazlasını bulmuş olacaklardı. Çünkü temelleri II. Akabe Biatı'nda atılan Devlet, sadece sözünü ettiğimiz kardeş kabilelerin derdine derman olmakla kalmayıp, başta Allah Resulü (sav) olmak üzere muhacirlerin de arayışına cevap olacaktır.

Bu devletin kurulduğu miladi 7. yüzyıl, Bizans ve Sasani imparatorluklarında olduğu gibi genellikle hanedanların yönetimde olduğu devletlerin asrıdır. Saltanat sistemine dayalı devletlerde ülke, üzerinde yaşayan kitlelerle beraber hanedanın malı sayıldığından bu tür sistemlerde millî iradeden bahsetmek mümkün değildir. Böyle bir çağda, Hz. Peygamber'in önderliğinde Medine' de kurulan bu devlette ümmetin iradesinin yönetime bir şekilde yansıtılması konusunun, “TBMM'nin 100. Y11ı ve Millî İrade" teması açısından üzerinde durulmağa ve irdelenmeye değer olduğu kanaatindeyiz.

Çalışmamız için öncelikle siyer kaynakları ve konuyla ilgili araştırmalardan istifade etmeye çalıştık. $\mathrm{Bu}$ arada ilgisi nispetinde tefsir ve hadis kaynaklarından da yararlandık. Konumuza ışık tutacağına inandığımız rivayetler ve bunlarla ilgili araştırmacılarımızın yorumları 1şı̆̆ında çalışmamızı temellendirmeye gayret ettik. Bir hukuki çözümleme yapma amacında olmadığımızdan, çıkarımlarımızı olabildiğince rivayetlerde sözü edilen konularla irtibatlı olarak bina etmeye çalıştık. Çerçevesini ve yöntemini ortaya koymaya gayret ettiğimiz bu çalışma, çok boyutlu bir mevzu olan hâkimiyet konusunun unsurlarından olan beşer iradesi esas alınarak oluşturulmaya çalışılmıştır. Bu araştırmanın, milletlere rağmen onları yönetmek yerine, yönetimin varlık sebebinin yönetilen insanların maddi ve manevi hayat standartlarının daha da

2 Tîn 95/3. 
artırılmasına matuf olması gerektiği gerçeğinden hareketle, "Milli İrade" konusunun gelişim serüveninde önemli bir halka olacağı inancındayız.

\section{Yönetimin Oluşturulmasında Milli İrade}

\subsection{Akabe Biatları}

Allah Resulü (sav), 610 yılında Mekke'de başladığı peygamberlik görevini sürdürürken, bir taraftan kendisini engellemeye çalışan muhalefetle mücadele ediyor, bir taraftan da kendisine inananlara kol kanat germeye çalışıyordu. Hz. Peygamber' in getirdiği dine inanan Müslümanlar, öteden beri sürdürmekte oldukları kabile yapısından tam olarak ayrıştırılıp kendilerini bir arada tutacak yeni bir yapıya kavuşturulamadığından, kabilelerinden bağımsız hareket edemiyorlardı. Bu durum, yeni Müslümanların dinlerinden dönmeleri noktasında bizzat kendi kabile büyükleri tarafından çeşitli baskı ve eziyetlere maruz kalmalarına neden oluyordu.(İbn Hişam, 1992, I, s. 210; İbn Sa'd, ts., III, s. 55) Hâşimoğullarının reisi Ebu Talib'in müsamahakâr tavrı nedeniyle, Hz. Peygamber'in kabiledaşları hariç, diğer Müslümanlar genellikle sözünü ettiğimiz sıkıntılarla karşılaşıyorlardı.(Belâzûrî, 1963, I, s. 199; İbn Abdilberr, ts., II, s. 460)

İşte bu gerçekten hareketle Allah Resulü (sav), imkânı olan Müslümanları, Habeşistan'a gitmeleri konusunda teşvik etti.(İbn Hişam, 1992, I, s. 214; İbn Sa'd, ts, I, s. 203) İki aşamada gerçekleşen Habeşistan hicreti, oraya giden Müslümanların can güvenliği ve din özgürlüğü sorunun çözülmesini sağladıysa da, göç edemeyenler açısından aynı problemler devam etmiştir. Öte yandan süreç içinde Hz. Ömer gibi toplumun önde gelenleri durumunda olanların da İslam'1 benimsemiş olması, müşrik liderleri daha da endişelendirdiğinden bu durum onları daha ağır yaptırımlar uygulamaya sevk etmiştir. Hz. Peygamber'in kabilesini topyekûn cezalandırmayı hedefleyen ve üç yıl süren sosyal ve ekonomik yaptırım kararı,(İbn Hişam, 1992, p. I,235; İbn İshak, 1981, p. 137; İbn Sa'd, n.d., p. I,208) beklenen ayrışmayı sağlamadığ1 gibi kabile mensuplarını birbirlerine daha da kenetlemiştir. Ancak bu sürecin hemen bitiminde $\mathrm{Hz}$. Peygamber'in hamisi durumundaki Ebu Talib'in hayatını kaybetmesi nedeniyle yerine geçen diğer amcası Ebu Leheb'in kabile himayesini kaldırması,(Ibn Sa'd, n.d., pp. I, 211) Allah Resulü (sav)'i himaye arayışına sevk etmiştir.

Bu amaçla gittiği Taif'ten de elinin boş olarak dönmesi,(İbn Hişam, 1992, I, s. 283; İbn Sa'd, ts, I, s. 210-212) O’nu yeni arayışlara yönlendirmiştir. Hac ve umre ibadeti için şehre dışardan gelen kabileleri dolaşırken Mekke yakınlarındaki Akabe mevkiinde karşısına çıkan 6 Hazrec'li, Risalet'in 11. yılında çağrısına olumlu cevap vermişlerdir.(İbn Hişam, 1992, I, s. 289290) Aslında Kureyş ile ittifak arayışında olan bu Hazreclilerin davete kulak vermelerinde, birlikte yaşadıkları Yahudilerin dillendirdiği “Ahir zamanda bir peygamber gelecek”(İbn İshak, 1981, s. 62-63) müjdesinin de etkisi az değildir.

Bundan sonra yeniden görüşmek üzere randevulaşan taraflar, ertesi y1l yine aynı yerde, bu sefer muhalifleri Evslilerden 2 kişinin de içlerinde yer aldığ 12 kişilik Hazreçli bir grup ile geleceklerdir. Hz. Peygamber'in bahsi geçen bu 12 kişiyle yaptığı görüşmede, daha çok dini içerikli şartların yer aldığı bir çeşit sözleşme de hayata geçirilecektir. Bu sözleşme, "I. Akabe Biatı"(İbn Hişam, 1992, I, s. 291-296; İbn Sa'd, ts, I, s. 219-220) olarak adlandırılmıştır.

Savaşla ilgili hükümlerin yer almamasından dolayı "kadınlar biatı" da denilen bu sözleşmede Medineliler Allah Resulü (sav) 'e "Allah'a hiçbir şeyi eş ve ortak koşmamak, hırsızlık yapmamak, zina etmemek, çocuklarını öldürmemek, iftira etmemek, hiçbir hayırlı işe karşı çıkmamak" konularında söz vermişlerdir. Daha çok dini içerikli konuların yer aldığı sözleşme, Hz. Peygamber (sav) ile Medineli Evs ve Hazrec'li müslümanlar arasında yapılan ilk akid olması açısından önem arz etmektedir. Aynı zamanda burada Mus'ab b. Umeyr'in Medine'ye muallim olarak gönderilmesi de kararlaştırılmıştır. (İbn Hişam, 1992, I, s. 291-296; İbn Sa'd, ts, I, s. 219- 
220) Bu adımla Allah Resulü (sav), Evs ve Hazrec arasında öteden beri devam etmekte olan hassas dengeye göre bir stratejinin izlenmesini de sağlamış olmaktadır.

Nübüvvetin 13.yılında aynı noktadaki buluşmaya 73'ü erkek 2'si kadın olmak üzere 75 kişi katılmıștır. Katılımın sadece bir yılda bu derece artış göstermesinde, Allah Resulü (sav)'in gönderdiği Mus'ab b. Umeyr'in Kureyşli ve tarafsız kimliği oldukça önemli olmuştur. Öte yandan Sa'd b. Muaz ve Useyd b. Hudayr gibi liderlerin de Müslümanlığı benimsemiş olmaları etkili olmuştur.

Hz. Peygamber (sav) bu buluşmaya amcası Hz. Abbas ile birlikte gitmiştir. Hem akrabalık hem de ticari ilişkileri nedeniyle özellikle Hazreclileri daha iyi tanıyan Hz. Abbas, Allah Resulü (sav) ile yaptıkları sözleşmenin ne anlama geleceği noktasında onları uyarmış ve tutamayacakları sözleri vermemeleri konusunda ihtar etmiştir. Akabinde Hz. Peygamber (sav) önceki sene alınan kararları tekrar ettikten sonra daha çok siyasi içerikli konular üzerine onlardan söz almıştır. Bu arada 9'u Hazrecli ve 3'ü de Evsli olmak üzere nakîpler/temsilciler belirlemiştir.(İbn Hişam, 1992, I, s. 221-223) Aynı zamanda bir akid olarak da değerlendirilen bu sözleșme, Medine'ye hicretin ve orada kurulacak devletin özellikle hâkimiyet unsurunun belirlemesinde bir ön hazırlık durumunda olmuştur. Allah Resulü (sav) hicretten sonra muhacirleri temsilen kendisi ve Ensar'1 temsilen de bu nakibleri bir araya getirerek bir devlet kuracaktır.

II. Akabe Biatı hem kurulacak devletin temellerinin atılmas1 hem de bu devletin kuruluşunda birinci derece pay sahibi olan Muhacir ve Ensar denilen kitlelerin iradelerinin ortaya konulması noktasında oldukça önemlidir. Bu adımın atılmasında en önemli pay sahibi olan Hz. Peygamber, önceki dönemlerde olduğu gibi sadece reis pozisyonundakilerin değil, bu görüşmeye katılanların tamamının hatta kadınların da biatını almıştır.(Ahmed b. Hanbel, ts, V, s. 379)

Hz. Peygamber'in özellikle devlet başkanlığı yaptığı süreçte birkaç kez tatbik ettiği "biat/bey'at" kurumuyla ilgili yeri gelmişken genel hatlarıyla ilgili bilgi vermek yerinde olacaktır. Arapların aralarında icra ettikleri ticari antlaşmaları teyit etmek amacıyla öteden beri alışageldikleri el sıkışma uygulamasından hareketle, idare edenle edilen arasındaki yetki devrine dayalı sosyopolitik akde biat/bey'at denilmiștir. Dilimizde biat olarak kullanılan bu kelimenin Arapça aslı "bey'attır". "Satmak; satın almak" manasındaki bey' masdarına bağlı olarak "yöneticilik tevdi etmek, birinin yöneticiliğini benimsemek" anlamında kullanılmıştır. Sosyopolitik bir akid olarak ise, devlet başkanını seçme, belirleme ve İslam hukuku çerçevesinde ona bağlılık gösterme anlamına gelmektedir. Devlet başkanını belirleme akdinin taraflarından biri (halk) yönetilme hakkını öbürüne devretmek, diğeri de (devlet başkanı) hukuka riayet etmek suretiyle bunun karşılığını ödemek üzere aralarındaki anlaşmadır.(Kallek, 1992, VI, s. 120-121)

Hz. Peygamber (sav) döneminde daha çok “dini hükümlere bağlı kalmak ve Resülullah'a (sav) itaat etmek" anlamında kullanılan biat, Hz. Ebu Bekir'in halife seçilmesinden itibaren sonraki kullanışlarına esas olacak siyasi bir mahiyet kazanmış, "bir devlet başkanını seçme yahut seçilmiş veya bu makama herhangi bir yolla gelmiş devlet başkanına bağlllık sunma" anlamında kullanılmaya başlanmıştır. Gerek dört halife döneminde görülen, gerekse sonraki dönemlerde ortaya çıkan uygulamalar bu kurumun teorik esaslarının belirlenmesinde önemli rol oynamıştır. (Kallek, 1992, VI, s. 121)

Bir kimsenin kendini yönetme iradesinin bir kısmını, güvendiği başka birine tevdi etme eylemine dayalı bir akid olarak kabul edilen biat, iki kişi arasında gerçekleştiğinden, hukuki bir uygulama olarak bunlara sözleşmenin tarafları denilmiştir. Sözleşmenin konusu ise "irade beyanı" olarak belirlenmiştir. İrade beyanı uygulamasının "kendimi yönetme irademin bir kısmını devrediyorum" şeklinde sözlü olarak beyanı yerine, uygulamada daha çok bahsi geçen tokalaşma ile irade devri söz konusu olmuştur. Söz konusu yetki devrinin çeşitli şekillerde baskı ile alınması genellikle kabul görmemiştir. Uygulamada farklılıklar olsa da hukukçular, Hz. Peygamber (sav) 
ve Raşid halifelerin uygulamalarından hareketle bu konuda icbar edilemeyeceği noktasında birleşirler. (Kallek, 1992, VI, s. 122; Kapar, 1998, s. 14-15)

Biat, uygulamada iki aşamalı olarak tatbik edilmiştir. İlk aşamasına seçim biatı, ikinci aşamasına da "genel biat/ bey'atü'l- âmme" adı verilmiştir. "Seçim biatı/bey'atü'l-hâssa", kendilerine Ehlü’l-hall ve'l-akd denilen sınırlı sayıdaki Müslümanın devlet başkanı olacak bir isim üzerinde ittifak ederek onunla el sıkışması şeklinde tarif edilebilir. Ehlü'l-hall ve'l-akd kavramı, halifeyi görevden alma ve yeni halife olacak kimse üzerinde ittifak sağlama yetkisine sahip olan komisyon/heyet olarak tanımlanabilir. Bunların kimlerden oluşması gerektiği hususunda tarihi süreç içinde muhtelif görüşler ortaya konulmuştur. (Kallek, 1992, VI, s. 122123)

\subsection{Medine Vesikası}

Akabe biatlarında Allah Resulü (sav) ile akitleşen Evs ve Hazrec kabileleri, miladi II. veya III. asırda anavatanları Yemen'den kalkıp Medine şehrine gelerek daha önce burada yaşayan Yahudiler'in himayesine girmişlerdir. Bu süreç içinde Yahudilerin sosyal, siyasi ve ekonomik baskılarına maruz kalmışlardır. Bunun üzerine Suriye'de ikamet eden akrabaları Gassaniler'in desteğiyle Yahudilerin reislerini öldürerek hem bağımsızlıklarını kazanmışlar hem de zaman içinde şehirde üstünlüğü ele geçirmişlerdir.(Önkal, 1998, XVII, s. 143-144)

Bunun üzerine Yahudiler farklı bir taktik izleyerek bu iki kabileye yakınlaşmışlardır. Buna göre Benû Kaynuka, Hazrec ile Benû Kurayza ve Nadîr de Evs ile ittifak kurmuştur. Bu ittifak1 firsat bilerek onlara yaklaşan Yahudiler bir şekilde bu iki kardeş kabileyi birbirine düşürmeyi başaracaklardır. Bu kabileler arasında çok sayıda savaş çıkmışsa da bunların en şiddetlisi hicretten beş yıl önce yapılan ve Evslilerin galibiyetiyle sonuçlanan Buas ${ }^{3}$ harbidir. İşte hem Evslileri hem de Hazreclileri Kureyşlilerle ittifak talebinde bulunmaya zorlayan asıl sebep, şehirde meskûn bulunan Yahudilerin kışkırtmasıyla ortaya çıkan düşmanlıklardan kurtulma çabasıdır. Aslında iki kardeş kabile olmalarına rağmen, bahsi geçen kesimin kışkırtmalarının üstesinden gelemediklerinden, kendileri için şehirdeki hayat giderek daha da tahammül edilemez hale gelmekteydi. Bununla birlikte Akabe'de yapılan ilk görüşmede Hz. Peygamber'in çağrısına Hazrecli 6 kişinin olumlu cevap verme sebeplerinden biri de, Yahudilerin "beklenen peygamber" üzerinden kendilerini tehdit etmeleridir. Rivayete göre; Evs ve Hazrecliler bir şekilde galibiyet elde ettiklerinde, Yahudiler ahir zamanda geleceği beklenen peygamberin yakında gönderileceğini ve kendilerine vereceği destekle Evs ve Hazreclileri tıpkı Ad, Semûd kavmi gibi helak edeceklerini iddia etmişlerdir. Allah Resulü (sav) 'in daveti onlara bahsi geçen tehdidi hatırlatmış ve Yahudilerden daha evvel onunla işbirliği yapmak için acele etmişlerdir. (İbn İshâk, 1981, s. 62-63)

Hicretten sonra Hz. Peygamber (sav)'in öncülüğünde, önce Ensar ve Muhacirlerin bir araya gelmesiyle, daha sonra Yahudilerin de dâhil edilmesiyle Medine Vesikası esas alınarak bir üst otorite oluşturulmuştur. Buna göre Müslümanlar ve Yahudiler ayrı federal yapılar olarak bir konfederasyon oluşturmaktadırlar. Şehirde yaşayan bütün insanlar "Medine Vatandaşlığı" (Apak, 2011, p. 249) ortak paydasında hukuki bir statü kazanmışlardır. Aynı zamanda onlar, diğer insanlardan ayrı bir ümmettirler. Şehir halkını oluşturan kabileler, yine şehir halkından bir başka kabile aleyhine olacak şekilde birilerine himaye verme veya işbirliğine girişemeyeceklerdir.(İbn Hişam, 1992, I, s. 351-353) Böylece süregelen düşmanlıkları oluşturan önemli bir etken ortadan kaldırılmaktadır. Bu durum aynı zamanda muhacirlerin düşmanı durumunda olan Kureyş ile

\footnotetext{
${ }^{3}$ Buas, Medine'nin güneydoğusunda yer alan bir vahanın adı olup Evs ve Hazrec kabileleri arasında meydana gelen son savaş burada cereyan ettiğinden bu ismi almıştır. Bu savaş Hicret’ten 5 veya 6 yıl önce meydana gelmiştir. Savaşın sebebi ise, Evsli bir şahsın Hazrec'e sığınan birini öldürmesidir. Savaşta Evsliler Hazrec reisi Amr’ı öldürerek üstünlük elde etmişlerdir. Bk. Çubukçu, Asri, "Buas", DİA, VI, s.340.
} 
muhtemel işbirliklerini de engelleyeceğinden, Akabe'de Hz. Peygamber'in talep ettiği himayeyi zedeleyecek adımların da önüne geçilmiş olmaktadır.

Kaynaklarımızda "Kitâb", "Sahîfe" ve "Muvâdaa" olarak zikredilen mezkûr vesikanın,(Özkan, 2016, Ek II, s. 212) yeryüzünde bir devletin vazettiği ilk yazılı anayasa olma özelliğine sahip olduğu kabul edilmektedir. Bu "Sahife", sadece devletin tek taraflı olarak vatandaşlardan taleplerini içermemekte, aynı zamanda devletin bir üst otorite olarak vatandaşlarına karşı sorumluluklarını da ihtiva etmektedir. Ünlü hukukçu Muhammed Hamidullah'1 (Muhammad Hamidullah, 1990, I, s. 189-210) bahsi geçen metni, tarihte ilk yazılı anayasa olarak nitelemeye sevk eden neden de, metnin bu yönüdür. Bu adım ile vatandaşa karş1 devletin sorumluluğu belirlenerek, şehir halkının iradesi kayıt altına alınmış olmaktadır.

Sonuç olarak; bu metin ile hem Hz. Peygamber'in himaye talepleri hem de Medineli Evs ve Hazrec mensuplarının içinde bulundukları sıkıntıları gidermeye yönelik tedbir ve çözümler kayıt altına alınmıştır. Şehrin sakinlerinden olan Yahudiler de ittifak halinde oldukları kurucu unsur üzerinden bir federal yapı olarak sisteme dâhil edilmiştir. ${ }^{4}$ Bunların yanında Allah Resulü (sav) açısından en önemli gerekçe olan İslam Davet'ini insanlara ulaştırabilmek (Ra'd, 13/40) için uygun ortam oluşturulması ve bunu engelleme girişimlerinin önlenmesi de temin edilmiştir. Böylece hem himaye talebiyle gelen muhacirler hem de şehrin sakinlerinin Akabe'de belirlenen hedefleri gerçekleştirilmiş olmaktadır. İlk adımı Akabe biatlarıyla atılan ve Medine Vesikası ile hukûkî bir zemine oturtulan yeni devlet, tamamen Ensar ve Muhacirlerden oluşan tarafların iradelerinin bir bakıma ete kemiğe büründürülmüş halidir. Bu da göstermektedir ki millî irade, gerek belli bir inancı esas alan yeni toplumun oluşturulmasında ve gerekse adaleti esas alan devletin teşekkülünde çok önemli bir unsur durumundadır.

\subsection{Yönetimin Emanet Olarak Değerlendirilmesi}

Arapça'da "güvenmek, korku ve endişeden uzak olmak" manasındaki "emn" mastarından gelen "emânet" kelimesi, hıyânetin zıt anlamlısı olarak 'isim' şeklinde kullanıldığı gibi "güvenilir olmak" anlamında 'mastar' olarak da kullanılır. Ayrıca "güvenilen bir kimseye koruması için geçici olarak tevdi edilen şey" manasına da gelmekte olup kelimenin bu son kullanılışı daha yaygındır.(İbn Manzûr, "emn”, mad)

Kur'an'da “Allah size emanetleri ehline vermenizi ve insanlar arasında hüküm verdiğiniz zaman adaletle hükmetmenizi emreder" meâlindeki âyette (Nisa 4/58) "güvenilen bir kimseye koruması için geçici olarak tevdi edilen şey” anlamında kullanılmıştır.

Meşhur müfessir Taberî’ye göre bu âyet, özellikle devlet adamlarının hem emanet hem de adalet ehli olmalarını gerekli kılmaktadır. Emanet ehli olmaları, ülkenin maddî imkânlarını halka haksızlık yapmadan paylaştırmalarıyla, adalet ehli olmaları da bütün kararlarında hukuka riayet etmeleriyle gerçekleşir. Öte yandan bu ayette belirtilen emanet kelimesi hem Allah'a iman etme, ona güvenme hem de kulun kendisinin ve başkalarının haklarını gözeterek onları da güvende hissettirmesi şeklinde birden fazla anlam zenginliğine sahiptir.(Taberi, 1968, IV, s. 145146)

Emanet kavramıyla ilgili bu açıklamalar değerlendirildiğinde üç unsurun öne çıktığ1 görülür: Bunlardan birincisi; yönetim görevi yöneticiye geçici olarak verilmiş bir emanettir. İkincisi; yönetim alanı güvenli mekânlar olmalıdır. Üçüncüsü ise; yönetim alanındaki varlıklar güven içinde olmalıdır. Bahsi geçen bu unsurlar aslında millî iradenin tecellisi açısından oldukça önemlidir. Sözünü ettiğimiz emanet kavramının açılımları mesabesindeki bu değerlerin, yönetim tarafından lâyıkı veçhile önemsenmesi ve icraata sokulması, yönettiği insanların talepleriyle

\footnotetext{
${ }^{4}$ Medine Sözleşmesi ile ilgili geniş bilgi için bk. Hamidullah, Muhammed, İslam Peygamberi, I, s.188-213.
} 
yöneticinin hassasiyetinin örtüşmesini gerektirecektir. bu da zaten yönetim aygıtının bir bakıma varlık sebebidir. Şimdi bunları sırasıyla biraz daha detaylandırmaya çalışalım:

Dini literatürde genellikle "el-Emr" (Âl-i İmrân 3/159 ) kelimesiyle ifade edilen yönetim/idare, "Bir toplumda belirli kurallar çerçevesinde meşru güç kullanma yetkisine sahip yegâne birim" olarak tanımlanabilir. Biat konusunda da sözü edildiği gibi, aday olarak belirlenen şahsa bey'at eden kimse; yönetici adayı ile kendi arasında bir çeşit sözleşme yapmış olmakta olduğundan, bunu temsilen tokalaşma eylemini gerçekleştirmektedir. Biat eden şahıs kendisine yaratılıştan verilmiş olan cüzî iradenin bir kısmını yine kendi özgür iradesiyle yöneticiye tevdi etmektedir. Yönetici adayıyla yönetilen arasında yapılan bu akid gereğince karşılıklı yetki ve sorumluluklar belirlenmekte ve taraflar ona göre hareket etmektedirler. Sözgelimi Hz. Peygamber (sav) ile Ensar arasında yapılan sözleşmede Medine şehrine her hangi bir saldırı olması durumunda, birlikte savunma yapılması söz konusu olduğundan, hicretin ikinci yılında cereyan eden Bedir Savaşı öncesinde (İbn Hişam, 1992, I, s. 449-450) bahsi geçen kesimin onayının alınmasına ihtiyaç duyulmuştur.

Yöneticinin kendisine tevdî edilen ümmet adına karar verme yetkisi emanet olarak değerlendirilmektedir. Konuyla ilgili sözü edilen ayette (Âl-i İmrân 3/159) de ifade edildiği üzere bu emanet, yöneticiye dinin yüklediği bir sorumluluk olduğundan, kendisine emanet tevdi edilen halife, vali gibi yöneticiler, sadece biatlarını aldıkları ümmete karşı değil, aynı zamanda Allah'a karşı da hesap verme bilinciyle hareket etmek durumundadırlar. Ümmetten alınan bu emanetin her şeyi bilen, gören ve ihlallerin hesabını soracak aşkın bir otorite tarafından murâkabe edildiği bilinci de yöneticinin verdiği sözü tutmasına katkı sağladığı için böyle bir yönetimde milli irâde daha etkin bir şekilde tecellî edecektir.

İkinci konu, yönetimin hâkimiyet alanına giren mekânların güvenli hale getirilmesi görevidir. Emanet bilincinin tabii sonucu olan bu görev, yöneticiye ilave bir vazife daha yüklemektedir. Yönettiği insanların yaşam alanının ve onların sahip oldukları taşınır-taşınmaz malların güven içinde olabileceği ortamların oluşturulmasıdır. Aslında güvenli ortamdan söz edilebilmesi için öncelikle bir üst otoritenin oluşturulması mecburiyeti kaçınılmazdır. Her kabilenin kendi güvenliğini sağlamak zorunda olduğu Medine örneğinden hareketle, sözünü ettiğimiz güven ortamı çok daha iyi anlaşılacaktır. Çünkü şehrin sakinleri birbirlerine kenetlenerek dışardan gelen saldırıları püskürtme yerine, dışardan sağladıkları destekle hemşehrilerini mağlup etmeyi tercih etmişlerdir. Diğer bir ifadeyle, Yahudilerin kışkırtmasıyla birbirlerine düşürülmüş kardeş kabileler olan Evs ve Hazreclilerin düşmanlıkları o dereceye varmıştır ki, şehir dışından düşmanın gelmesine gerek kalmamıştır. Öyle ki bu düşmanlık her iki tarafı da bıktırmış olduğu için, bu kabileler, özellikle aralarının düzeltilmesi talebiyle Kureyş'in hakemliğine muhtaç duruma düşmüşlerdi. İşte böyle bir ortamda yaşama tutunmaya çalışan şehir halkı, himâye talebiyle Mekke'den göç eden Hz. Peygamber'i Kureyş'i karşılarına alma pahasına başlarına reis olarak seçmişlerdir.

Allah Resulü (sav), "Medine Vesikası" adıyla meşhur olan akid/sözleşme ile çerçevesini belirlediği üst otoriteden aldığı yetkiyle sözünü ettiğimiz düşmanlıkları ortadan kaldırdığı gibi, şehir halkının enerjisini muhacirlerin de desteğiyle dış güçlere yöneltmeyi başaracaktır. EnsarMuhacir kardeşliği ile iki kesimi birbirleriyle kenetleyerek (Haşr 59/9) hem muhacirlerin himaye ihtiyacını giderecek hem de onların Kureyşli oluşlarının getirdiği vizyon (Uslu, 1998, XVIII, s. 364-364) ile, şehirde bahsi geçen güven ortamını oluşturmayı başaracaktır. Öyle ki, Hazrecliler tarafından hicretin hemen öncesinde reis olarak seçilen Abdullah b. Übey b. Selul'ün (İbn Hişam, 1992, I, s. 423-426) başkanlığının rafa kaldırılmış olması en azından söz konusu kabilenin önde gelenleri açısından önemli bir sorun olarak değerlendirilmeyecektir.

Üçüncü sırada yer alan yönetilenlerin güven içinde hayatını idame ettirmesi ise; ikinci maddedekine benzer bir durum gibi gözükmektedir. İkinci sıradaki husus, yönetim alanının 
güvenli hale getirilmesi iken, bahsi geçen ortamda yaşayanların güven içinde hayatlarını sürdürmeleri söz konusu olduğu için oldukça farklıdır. Mevzuyu gayr-1 Müslimlerin müslüman toplum içindeki pozisyonu örneği ile açmaya çalışalım. Her şeyden önce İslam hukuku bu kesimi "Ehl-i zimmet"(Yaman, 2013, s. 44, 434) olarak adlandırmaktadır. Buna göre bahsi geçen kesimin yönetim tarafından güvenlikleri garanti edilmiş demektir. Peki, bunların güvenlikleri kimin tarafından sağlanacak denilirse, bunun cevabı; Müslüman toplum tarafından olacaktır. Hz. Peygamber (sav) bizzat kendi yönetiminde bu imkânı onlara sağladığı gibi sonraki halifeler döneminde de bu durum dikkate alınarak tatbikat yerine getirilmiştir. Medine Vesikası dikkate alındığında bu kesimlerin gerek dini ve gerekse hukuki anlamda özerk yapılar haline getirildiği görülür. Şehirden ihraç edilme veya kılıçtan geçirilme cezaları ise, ya kendi hukuklarının gereği olarak veya müttefikleri olan kabile reisinin hakemliği ile verilen kararlara göre tatbik edilmiştir.(İbn Hişam, 1992, II, s. 573-574)

Sonuç olarak, yönetimin idareci tarafindan emanet olarak algılanması gerektiği hususu, çağımızda "ileri" diye nitelendirilen yönetim sistemlerinin çok daha ilerisinde olduğu, bahsi geçen örneklerde görülmektedir. Bu örnekleri gerek Hz. Peygamber (sav) ve gerekse sonraki halifeler dönemi tatbikatlarıyla çoğaltmak mümkündür. Bunun en önemli göstergesi, Endülüs, Balkanlar gibi daha önce Müslümanlar tarafından yönetilirken şu anda farklı din mensupları eliyle yönetilen coğrafyalarda hala varlıklarını devam ettirebilen Hıristiyan veya Yahudi toplumudur. Fakat bahsi geçen yerlerdeki ağırlıklı olarak Müslümanların işbaşında olduğu yönetim birimleri ortadan kaldırıldıktan sonra orada yaşayan Müslümanların başına gelenler tarihen bilinen hususlardır.(Özdemir, 2005, XXX, s. 288-291).

\subsection{Hz. Peygamber'in Kendisinden Sonraki Halifeyi Belirlememesi}

Hz. Peygamber, miladi 632 yılında vefat etmiştir. O'nun ahirete irtihali, Sahabe-i Kiram'1 Peygambersiz hayata intibak ve yeni halifenin belirlenmesi sorunuyla karşı karşıya getirmiştir. (İbn Hişam, 1992, II, s. 1088) Böyle bir atmosferde daha çok muhacirler Allah Resulü'nün teçhiz ve tekfin işleriyle uğraşırken, Ensar'ın Benû Saide Sakifesi'nde halife adayını belirlemek için toplandıkları haberi, özellikle Müslümanların önde gelenlerinin olaya müdahil olmalarını gerektirmiştir. (İbn Hişam, 1992, II, s. 1071-1076) Daha Hz. Peygamber (sav)'in cenazesi ortadayken organize edilen bu toplant, Hz. Ebu Bekir, Hz. Ömer ve Ebu Ubeyde b. Cerrah'in katılımıyla ümmetin çoğunluğunun kabul edebileceği bir karar ile sonuçlandırılacaktır. Çünkü Hz. Ebu Bekir, başkent Medine'nin siyasi otoritesine karşı ülkenin birçok yerinde başlatılan isyan/irtidat hareketlerini bastırmak ve yeniden kabilelerin itaatini sağlamak için mutlaka Kureyşli bir reis olması gerektiği noktasında onları ikna etmeyi başaracaktır. Bunun üzerine hem Ensar'ın hem de muhacirlerin önde gelenleri, Hz. Ebu Bekir'in adaylığı noktasında mutabık kalacaklardır. Ertesi gün de başkentteki Müslüman erkeklerin katılımıyla Hz. Peygamber'in vefatından sonra O'nun riyaset görevini yerine getirmek üzere ilk halife seçilecektir.(Buharî, 2002, Fezâilu'l-Ashab 5; İbn Hişam, 1992, II,; İbn Kuteybe, 1967, I, s. 16-17; İbn Sa'd, ts, II, s. 269; Vâkı1î, 1990, s. 41-42)

Ana hatları bu şekilde ortaya konulabilecek hadise, ilk bakışta bir başıboşluk durumunu akla getirmektedir. Muhacirler, Hz. Peygamber (sav)'in yasını tutma ve cenaze işleriyle ilgilenirken, Ensar'ın belki de ev sahibi olduklarından hilafet kaygısına düştüğü gözlenmektedir. Allah Resulü (sav), vahiy destekli gayretiyle, Ensar ve muhacirleri bir araya getirerek yeni bir otorite oluşturmayı başardığı gibi yaklaşık on yıl bunu kendi riyâsetinde sürdürmüş̧tür. Risâlet görevi, vefatıyla birlikte sona erse de,(Ahzâb 33/40) devam etmesi gereken riyâset görevi için, kendisinden sonra bu işin kimin tarafindan sürdürüleceği hususunda doğrudan veya dolaylı bir beyanda bulunmamıştır. (İbn Sa'd, ts, II, s. 242-245) Nitekim bu konuda Şia bazı görüşler ortaya koysa da, süreç içinde kendilerinden olan âlimler dışındaki İslam bilginleri tarafından genelde kabul görmemiştir. 
Müslümanların bir kısmı çok değer verdikleri Allah Resulü (sav)'in cenazesiyle meşgul iken Ensar'ın hilafet işine yönelmiş olması, belki de ilk bakışta yadırganabilir. Ancak Ensar'ın bu girişimi, Medine'nin ev sahibi olmaları nedeniyle yönetim işinin zaten kendilerinin sorumluluğunda olduğu gerçeğinden hareketle izah edilebilir. Diğer bir ifadeyle muhacirler bir bakıma misafir mesabesinde olduklarından, onların şehirdeki varlıkları geçici olduğunu düşünerek böyle bir davranış sergilemiş olabilirler. Nitekim Mekke Müslümanlar tarafından fethedilince Ensardan bazıları Allah Resulü (sav)'in artık Medine'ye dönmeyeceği düşüncesine kapılarak mahzun olmuşlardır. Onların durumunu gören Hz. Peygamber (sav), "Öyle bir şeyden Allah'a sığınırım. Benim hayatım sizin hayatınızdır, benim ölümüm sizin ölümünüzdür” (İbn Hişam, 1992, II, s. 865) sözleriyle onları teselli etmiştir.

Vefatından yaklaşık 3 ay önce yaptığı veda haccında îrâd ettiği hutbesinde "Belki bu seneden sonra sizinle bir daha buluşamam"(Buharî, 2002, Meğâzî 77; İbn Hişam, 1992, II, s. 1021; İbn Sa'd, ts, II, s. 184-186) mealindeki sözlerinde, sanki artık ahirete irtihalinin yaklaştığ bilgisine sahip olduğu gibi bir izlenim hissedilmektedir. Buna rağmen kendisinden sonraki halifenin kim olacağı hususunda herhangi bir işaret veya beyanda bulunmamıştır. 23 yıllık nübüvvet döneminde her hususta son derece tedbirli olan Hz. Peygamber'in bu tutumunu "hazırlıksız yakalanmak", "gafil avlanmak" veya bunun gibi ihmalkârlığa dayalı bir tavır ile izah etmek mümkün değildir. Öyleyse Allah Resulü (sav)'nün bu tavrının bilinçli bir adım olduğu ortadadır.

Bilindiği gibi Hz. Peygamber, Sahabe-i Kiram'a çok düşkün,(Tevbe 9/128) onların yetiştirilmesi konusunda önemli adımlar atmış bir rehberdir. Bir kısım hadislerinde onların bu yönlerini öne çıkardığı ${ }^{5}$ bilinen bir husustur. Ayrıca İslam'ın sahabe ve onların yetiştirdiği tabiin nesli eliyle geniş coğrafyalara ulaştırılıp hayatın her alanında tatbik edildiği ${ }^{6}$ tarihen sabit olan bir husustur. Bu derece bilinçli ve ne yaptığının sorumluluğunu bilen ve ona göre geleceğe yönelik planlamalar yapan bir Peygamber (sav) eliyle yetiştirilmiş bu neslin, Allah Resulü (sav)'ne karş1 son derece itaatkâr aynı zamanda muhatap oldukları soruna çözüm üretme noktasında mahir oldukları bilinen bir husustur. Bütün bu gerçeklerden hareketle, sözünü ettiğimiz konuda $\mathrm{Hz}$. Peygamber (sav)' in bir işarette bulunmaması veya bir kimse üzerinde herhangi bir hazırlık içinde bulunmaması, onların ferasetine olan güveniyle izah edilebilecek bir husus olmalıdır. Sonuç olarak Hz. Peygamber (sav), 23 y1llık nübüvvet döneminde olduğu gibi, bu dünyadan göç ettiği aşamada ortaya koyduğu tasarrufla da sahabe-i kirama güvendiğini ve bu hususta onların vereceği karara olan itimadını ortaya koymuş olmalıdır.

\section{Toplumun (Ümmet) Oluşturulmasında Milli İrade}

Hicretten önce Yesrib'de Kaynuka, Nadîr ve Kurayza kabilelerinden oluşan Yahudiler; Yemen kökenli Evs ve Hazrec adlı Arap kabileleri; Kudâa ve Amâlika kabilelerinin bakiyeleriyle çeşitli etnik kökenlerden köleler bulunuyordu. Bunlar yerleşik hayata geçmişlerse de bedevi hayatta olduğu gibi kendi kabile reislerinin riyasetinde yaşamaya devam ediyorlard1.(Duri, 1991, p. 81) Kabileler üstü bir siyasi otorite anlayışına erişemediklerinden sürekli kabile çatışmaları cereyan ediyordu. Bu durum özellikle şehrin Yemen kökenli Arap kabileleri Evs ve Hazrec'i mağdur ettiğinden her iki kabile de bu durumdan kurtulmak için arayış içindeydi.(Muhammad Hamidullah, 1990, I, s. 149-150) Nitekim Farabi belki de bu yüzden "medine"”yi coğrafi ve doğal bir topluluk olmaktan ziyade, iradî yani birbirlerinin karşılıklı haklarını koruyacaklarına dair sözleşen bir topluluk olarak değerlendirir.(Kutluer, 1972, XXVIII, s. 296)

\footnotetext{
${ }^{5}$ Bk Hadis külliyatlarının “Fedâilu Ashabi’n-Nebi, fezâilü'l-ashâb, menâkıbü's-sahâbe” bölümleri

${ }^{6}$ Bk Tartışmalı İlmi Toplantılar Dizisi çerçevesinde yapılan sempozyumlarda sunulan bildirilerin Ensar Neşriyat tarafından İslam Medeniyetinin Kurucu Nesli Sahabe I, II, III, IV ve V adıyla kitaplaştırılmıştır.
} 
Önceki satırlarda sözü edildiği gibi, Hz. Peygamber'in İslam'1 tebliğ için uygun ortam arayışı ile Yesrib'li Evs ve Hazrec'in bahsi geçen anlaşmazlıkların getirdiği tükenmişlikten kurtulmak için bir arabulucu talebi her iki kesimi ortak bir noktada buluşturmuş̧ur. Süreç içinde yapılan biatler ve akabinde muhacirlerin hicretiyle Yesrib şehrinde yeni bir oluşum için ilk adım atılmıştır.

\subsection{Mescid}

Medine'de İslam toplumunun oluşmasında ve Müslümanlar arasında birlik beraberliğin sağlanmasında en önemli unsurlardan birisi Mescid-i Nebi'dir. Hz. Peygamber (sav) bunun için hicretten hemen sonra devesinin çöktügü yere, arsa ücretini bizzat kendisi ödeyerek bir mescit yaptırmak için harekete geçmiştir. Aslında Müslümanlar namaz emriyle birlikte hicretten önce kabile düzeyinde de olsa mescitler inşa etmişlerdi. Nitekim Allah Resulü (sav)'in mescit yaptırmak için girişimde bulunduğu yerde de Es'ad b. Zürare'ye ait bir mescit vardı.(İbn Hişam, 1992, I, s. 343) Şu andaki girişim ise şehirde dağınık halde yaşayan Müslümanların haftada bir defa da olsa bir araya gelebilecekleri "Cuma Mescidi" pozisyonunda merkezi bir mekân oluşturma girişimiydi. Çünkü bu usul, bahsi geçen ortak hedeflere ulaşmanın en uygun yöntemiydi. Bunun için başta Hz. Peygamber (sav) olmak üzere bütün sahabiler tüm imkânlarını seferber ederek çalışmışlardır. Yaklaşık 6 aylık bir sürede inşa edilen mescid, bir mabet olmanın yanında sosyal, siyasi, askeri birçok fonksiyon icra eden çok yönlü bir mekân olmuştur. (İbn Hişam, 1992, I, s. 343) Ancak belki de bunların en önemlisi; Müslümanların birbirleriyle ve hem Peygamber hem de devlet başkanı olan Hz. Peygamber (sav) ile kaynaşmalarını sağlamak olmuştur. Allah Resulü (sav) liderliğinde Sahabe-i Kiram'ın geçmişten kalan husumetleri giderilmiş ve gönülleri birbirlerine 1sınmıştır. "(Âl-i İmrân 3/103).

$\mathrm{Bu}$ mescid, Hz. Peygamber (sav) döneminde savaş stratejilerinin belirlenmesi, Hz. Ayşe'ye atılan iftira konusunda nasıl bir yol izleneceği gibi birçok sosyal ve siyasi konuların belirlenmesiyle, O'nun vefatından sonra da halifelerin seçimi konularında millî iradenin tecelli ettiği önemli bir mekân da olmuştur.(Muhammed Hamidullah, 1992, s. 64-76).

\subsection{Muâhât}

Gerek Mekke ve gerekse Medine halkı her ne kadar yerleşik hayata geçerek bedevi hayatın konargöçer özelliğinden kurtulmuşlarsa da, kabile esasına dayalı yaşam tarzından kurtulamamışlardı. Bundan dolayı şehir hayatının sağladığı imkânlardan yeteri kadar istifade edemiyorlard. Bunun tabii bir sonucu olarak, sözgelimi ortak bir güvenlik sistemi oluşturamıyorlardı. Yine bu durumun yansımalarından birisi, kabile rekabetleridir ki, daha kalitelisini yapmaya dayalı üretimi teşvik eden bir rekabet yerine rakibini bertaraf etmeye dayalı muhatabını ezici bir yarış söz konusuydu.(Duri, 1991, s. 81) Bu durumu Yüce Rabbimiz "Sizler düşmanlar idiniz, Allah kalplerinizde ünsiyet peyda ettirdi ve O'nun nimeti sayesinde kardeşler oldunuz, hâlbuki siz, aşağısı ateş çukuru olan bir uçurumun kenarında idiniz"(Âl-i İmrân 3/103) buyurarak Müslüman olmadan önceki durumu gönderdiği ayetle tasvir etmektedir.

Aslında Hz. Peygamber (sav) kabile esaslı yapıyı kırmak ve yerine inanç esaslı bir yapı ikame etmek için daha Mekke şartlarında Müslümanların kaynaştırılması uygulamasına girişmiştir. $\mathrm{Bu}$ teşebbüsün, içinde bulunulan şartlar itibariyle beklenen sonucu verdiği söylenemez. Bundan dolayı Medine'ye hicret edildiğinde, yeni bir toplum oluşturma amacina yönelik olarak atılan önemli adımlardan birisi; Ensar ile Muhacirleri kardeşleştirme girişimidir.(Demircan, 2013, s. 9) İlk etapta muhacirlerin yeme, içme, barınma gibi zaruri ihtiyaçlarını gidermeyi hedefleyen bu uygulama, orta ve uzun vadede inanç ortak paydasını esas alan yepyeni bir yapı oluşturmayı hedeflemiştir. Köle kökenli Zeyd b. Harise ile Kureyş'li Hz. Hamza'nın veya Kahtanîlerin Benû Ezd kolundan Evs ve Hazrecli Ensar ile, yine asaleti dillere destan olan Kureyşli muhacirlerin yakınlaştırılma gayreti (İbn Hişam, 1992, I, s. 304-305) bahsi geçen inanç temelli yapının gereklerindendir. Diline, rengine, kavmine vb. doğuştan gelen özelliklerin yerine, üstünlüğün ölçüsünü daha takvalı olmaya endeksleyen bu yeni değer 
ölçülerini Müslümanlar benimsemekte zorlanmamışlardır. Dahası Mute savaşında âzadlı köle Zeyd b. Harise'nin komutanlığı altında yüzlerce Kureyșli müslüman savașmıștır. (İbn Hișam, 1992, II, s. 828) Yine Hz. Peygamber (sav) son günlerinde Bizans'a karşı hazırladığı ordunun komutanlığına da bahsi geçen Zeyd'in genç yaştaki oğlu Üsame'yi görevlendirmiştir. (İbn Hişam, 1992, II, s. 1026)

Bütün bunlara ilaveten bu şehirde yaşayan Yahudiler de en azından siyasi olarak bu toplumun bir unsuru olmuşlardır. (İbn Hişam, 1992, I, s. 351) Bahsi geçen anayasada konfederasyon bünyesinde federal bir yapı olarak yer alan Yahudiler ile Müslümanların etkileşimi sınırlı seviyede olmuştur. Ehl-i kitap olduklarından, Müslümanlar kendileriyle iletișim kurmak ve asgari müşterekler muvacehesinde yakınlaşmak için çaba göstermişlerse de (Âl-i İmrân 3/64) kendilerinin seçilmiş bir toplum olduklarına dair inançları (Bakara 2/47) buna engel olmuştur. Muhtelif sebeplerden dolayı kendileriyle iyi ilişkiler kurulamayan Yahudiler, Vesika'da belirlenen kurallara muhalefet ettikleri gerekçesiyle bir şekilde cezalandırılmışlardır. (İbn Hişam, 1992, II, s. 573)

Hz. Peygamber (sav)'in bu şehirde oluşturduğu toplum, Evs ve Hazrec mensuplarının beklentilerine fazlasıyla cevap vermiştir. Çünkü sadece onların kendi kabileleriyle ilgili beklentileri değil, aynı zamanda Hz. Peygamber (sav) ve muhacirlerin beklentilerinin yerine getirildiği gibi, bütün dünyaya emsal olacak tarzda "Birlikte Yaşama Tecrübesi"7 örneği oluşturulmuştur. Öte yandan sadece bu şehirdeki birlikten yoksun olma durumunun getirdiği mahrumiyetleri gidermekle yetinilmeyip, takriben bütün Arap Yarımadasını içine alacak şekilde birlik ve beraberlik kurulmuştur.

\subsection{Medine}

Hz. Peygamber (sav) kendisine inananlarla birlikte o zamanki adı "Yesrib" olan Medine şehrine hicret etmiştir.(İbn Hişam, 1992, I, s. 335) Önceki satırlarda sözü edildiği gibi şehir halkının daha çok ortak bir otorite etrafında bütünleşememiş olmalarından dolayı sürekli birbirleriyle çatışma halinde oldukları bilinmektedir. Allah Resulü (sav), Kureyş kökenli bir Peygamber olmasının da katkısıyla ama öncelikle şehir halkının iradesi gereğince bu şehirde kurduğu otorite ile bahsi geçen sıkıntıları ortadan kaldırmaya çalışmıştır. (İbn Hişam, 1992, I, s. $351)$.

Bu çerçevede atılan önemli adımlardan biri de, insanın yerleşik hayata geçiş serüveninde tatbik etmek zorunda olduğu hususlardan biri olan hayatın zorluklarının paylaşarak üstesinde gelme anlamına gelen işbölümü uygulamasıdır. İnsanın sosyal bir varlık olmasının tabii neticelerinden olan bu uygulama, İslam medeniyetinin en önemli adımlarından biri olarak tarihteki yerini alacaktır. Nitekim şehrin Yesrib olan adının yerine tercih edilen Medine isminin anlamlarından biri de; "temeddün edinilen/şehirleşilen yer" anlamında olması, (Kutluer, 1972, XXVIII, s. 296) sözünü ettiğimiz iş bölümünün esas alındığını hatırlatmaktadır. Çünkü iş bölümüne dayalı olmayan birlikte yaşamaya şehirleşme denilemeyeceğinin apaçık göstergesi, bu şehirde hicretten önce yaşanılan hayattır. Yukarıdaki satırlarda söz konusu edildiği gibi, hicret öncesinde üst seviyede bir otorite tarafından organize edilmemiş olduklarından, birlikte yaşamın hayatı kolaylaştıran bir avantajı değil de zorlaştıran yönü daha çok ön plandaydı.

Hz. Peygamber (sav)'in bu şehirde oluşturmaya çalıştığ 1 toplumun inançlı bir toplum olmasının gereği olarak hem Allah'a hem de hemşehrilerine karşı dinin belirlediği ilkeleri esas alarak konumlandığı bilinen bir husustur. Meşhur Ensar-Muhacir kardeşliğine göre özellikle Ensardan olanların Muhacir kardeşlerine karşı ne kadar yardımsever ve fedakâr oldukları ayetlere dahi yansımıştır.(Haşr 59/9) Örneklerini çoğaltmak mümkün olmakla birlikte sözünü ettiğimiz

\footnotetext{
${ }^{7}$ Geniş bilgi için bk. Demircan, A. (2016). İslam Tarihinin Illk Döneminde Birlikte Yaşama Tecrübesi, İstanbul: Beyan Yayınları.
} 
durumun bahsi geçen isimlendirmeyi de etkilediği düşünülebilir. Nitekim Medine kelimesinin kökeninde bulunan, d/y/n harfleri "din" ve "deyn" kelimeleriyle ortak kökene sahiptir. D/y/n kökünden türeyen "d i n" kelimesi; "kulların Allah'a karşı vazifelerini bildiren ibadet, hüküm, ceza, boyun eğme, yaşama tarzını", "d e y n" ise; "kulların diğer kullara karşı davranışlarını düzenleyen, borçluluk ilişkilerini belli bir disipline koyan kurallar" anlamlarını taşımaktadır.(İbn Manzûr, ts, d/y/n mad.) Bu gerçeklerden hareketle Hz. Peygamber (sav)'in şehir halkının gönlüne yerleştirdiği inançların, onların hem Allah'a karşı sorumluluk bilinciyle hareket etmelerini hem de birlikte yaşadıkları hemşehrilerine karşı çok daha müspet tavır ve davranışlar içinde olmalarını sağlamıştır.

\subsection{Kabilecilikten Din Kardeşliğine}

Hicaz bölgesindeki halk bedevi de olsa, hadari de olsa kabilecilik esasına göre yaşamaktaydı. Bunların içinde en gelişmiş olanı Mekke olup siyasi yapılanma açısından diğerlerinden fark1, kabileler birliği durumunda şehrin karar ve yürütme organı mesabesindeki Dâru'n-Nedve'ye (İbn Hişam, 1992, I, s. 89) sahip olmasıdır. Her ne kadar Mekke, esnek yapı1ı bir birliğe sahip olmuşsa da, yine de asıl olan kabile idi. Medine'de ise bahsi geçen türden bir birlikten bahsedilmesi de mümkün değildi. Birlikten yoksun olmak, öncelikle güçsüz kabileleri mağdur etse de, netice itibariyle bu mağduriyetten bütün toplum sıkıntı çekmekteydi.

Allah Resulü (sav), muhacirlerle birlikte bu durumdaki Yesrib şehrine hicret edip öncelikle bir merkez olarak Mescid-i Nebi'yi inşa etmiştir. Akabinde Muhacir-Ensar kardeşliğini tesis etmiş, daha sonra da Yahudiler başta olmak üzere şehirde yaşayan diğer unsurları yeni yapıya dâhil etmiştir. Hep birlikte Medine Sözleşmesi ile belirlenen kurallar çerçevesinde oluşan "üst otoriteyi" yaşatmaya çalışmışlardır. Hz. Peygamber (sav) süreç içinde Müslümanların birlik ve beraberliklerini takviyeye yönelik olarak; ibadete çağrı şekli olan Ezanın belirlenmesi, kıblenin tahvili, Ramazan ve Kurban Bayramları, oruç ve zekât ibadetinin farz kılınması gibi daha çok toplumsal kurumları hayata geçirmiştir.(İbn Hişam, 1992, I, s. 357)

$\mathrm{Bu}$ toplumun kurucu unsurları durumundaki Ensar ve Muhacirleri bir araya getiren ana öğe, nihayetinde inanç bağıdır.(Demircan, 2009, s. 36-49) Tarafların öncelikle himaye ve aralarındaki ihtilafları giderme gibi talepleri olsa da, iman kardeşliğinin getirilerini görüp yaşadıkça, bu hedefe odaklanmışlardır. Bundan dolayı inanç bağının, birlikteliği sürdüren ana unsur olduğunu söylemek hiç de zor değildir. Zaten inanç gibi ulvi nitelikli bağlayıcı bir etken ancak aralarındaki ayrılık sebeplerini ortadan kaldırabilirdi. Çünkü ait oldukları kabileler itibariyle hem muhacirler hem de Ensar birbirleriyle rekabet içindeki kabilelere mensup idiler. Aynı zamanda "Kureyş'in üstünlüğü” (Uslu, 1998, XVIII, s. 364-364) fikri de söz konusuydu. $\mathrm{Bu}$ özelliğinden dolayı muhacirlerin, Kahtanî Araplarından Evs ve Hazrec mensuplarından himaye talep etmesi, bir zillet idi. Nitekim Kureyşli müşrik liderler kabiledaşları durumundaki muhacirleri himaye ettiklerinden dolayı Ensarı tehdit eden mektuplar yazmışlardı.(Ebu Davud, ts, Harâc 23)

Diğer unsurlar kategorisinde sözünü ettiklerimizden olan Yahudiler'in bu birlikteliğe dâhil olmalarını anlamak güçtür. Çünkü din mensubiyetleriyle sosyal, kültürel ve ekonomik durumları itibariyle muhataplarına göre daha teşkilatı bir yapıya sahip olduklarından böyle bir birlikteliğin, kendileri için getirisinin ne olacağını düşündüklerini kestirmek zordur. Belki de, Yahudiler başlangıçta, "bunlar nasıl olsa bize muhtaç olacaklar, böylece biz bunları etki altına almayı başarırız" diye düşünmüş olabilirler. Nitekim bu süreçte nazil olan ayetlerden (Âl-i İmrân 3/24) ve neler yaptıklarıla ilgili rivayetlerden (İbn Hişam, 1992, I, s. 423) böyle bir sonuca varmak mümkündür.

Aslında bu birliktelik, Adnânî-Kahtânî ayrılığı hatırlanırsa, Arap milleti açısından da oldukça önemli bir dönüm noktasıdır. Çünkü Arapların aynı zamanda belki de ilk defa ulus düzeyinde birlik olmalarının da ilk adımını oluşturacaktır. Bundan sonra civar şehir ve kabileler 
de bu birlikteliğe dâhil edilecek ve nihayetinde Arap Yarımadasının kuzey tarafları hariç olmak üzere Hz. Peygamber (sav) döneminde tamamı kapsam alanına eklenecektir.

Öte yandan bu birliktelik, inanç bağını esas alan bir yapıya sahip olsa da, diğer din mensuplarına da aynı bünye içerisinde ve eşit haklara sahip olarak hayat hakkı tanıması nedeniyle belki de tarihte bir ilk olma özelliğine sahiptir. Aynı zamanda insan topluluklarının bir arada nasıl yaşayabilecekleriyle ilgili ideal bir yapı olma özelliğini de ortaya koymaktadır.

Bahsi geçen dönemdeki büyük devletlerin sosyal yapıları ve siyasi hayata katılım durumları dikkate alındığında bu yapının önemi kendiliğinden ortaya çıkar. Gerek Bizans ve gerekse Sasanilerde hanedan mensupları dışındaki halkın egemenlik haklarının hiç olmadığını (Demirkent, 1992, VI, s. 230-244; Naskali, 2009, XXXVI, s. 174-176) hatırlarsak, Medine 'de oluşturulan ideal yapı içerisinde ne kurucu unsur ne de kurucu unsurun dindaş1 olmayan Yahudiler'e en az onlar kadar inisiyatif tanınmış olması,(Muhammad Hamidullah, 1990, I, s. 193) ideal yapının değerini bir kat daha artıracaktır. İçinde yaşadığımız çağda dünyanın gitgide küçük bir köye dönüşüyor olması da bu yapının ne kadar önemli olduğunu daha anlaşılır hale getirmektedir.

\section{Sonuç ve Öneriler}

Bu çalışma, başta Hz. Peygamber (sav) olmak üzere Muhacirlerin Medine’ye hicreti ve sonrasında oluşturulan toplum ve devletin oluşumunda millî iradenin rolünü ortaya koymak için kaleme alınmıştır. Daha önce Medine'de birbirlerine entegre olmadan yaşamını sürdüren kabilelerin hâkimiyet sahibi bir otoriteden mahrum oluşları, giderek daha da çekilmez hale gelen sorunların ortaya çıkmasına neden olmuştur. Belki de bu sorunlardan daha çok etkilenen Evs ve Hazrec mensupları, karşı karşıya oldukları problemlerin çözümüne katkı sağlar beklentisiyle farklı zamanlarda Kureyş kabilesinden yardım talebinde bulunmak üzere yola çıkmışlardır. Bu arada Mekke şehrinde peygamberliğini ilan etmiş ve şehirdeki tebliğ faaliyetlerinden dolayı kendi kabilesinin önde gelenlerinden gördüğü rahatsızlıklar sebebiyle görevini hakkıyla yapabileceği bir yer bulabilmek için himaye talebi arayışına giren Hz. Peygamber (sav) ile Akabe'de karşılaşarak taleplerini birbirlerine iletmişlerdir.

Karş1lıklı olarak mutabık kaldıkları bir plana göre, öncelikle Muhacirler Yesrib şehrine göç etmişlerdir. Bu şekilde bir araya gelen taraflar, ilk olarak kendi aralarında, sonra da diğer din mensuplarının da dâhil edildiği ortak bir otorite etrafında toplanmışlardı. Bu otorite, Medine Vesikası olarak bilinen aynı zamanda tarihte ilk yazılı anayasa olarak da kabul edilen bir metin olup, hem devletin hem de vatandaşların görev ve yetkilerini tanımlamıştır. Buna göre taraflar belirledikleri hedeflere ulaşmak için çalışmışlardır. Ancak burada sözü edilmesi gereken önemli unsurlardan biri de, tarafların tek başlarına ulaşamadıkları hedeflere birbirlerine destek olarak ulaşmış olmalarıdır.

Netice itibariyle Akabe'de tarafların belirlediği hedefler, katılanların milli iradeleri doğrultusunda hayata geçirilmiştir. Bunlardan Evs ve Hazrec mensuplarının talepleri yerine getirilmekle birlikte, süreç içinde onlar da Hz. Peygamber (sav) ile aynı hedefe odaklanarak, aralarında güç ve imkân birliği yapıp, İslam'ın tebliği için gece gündüz demeden çalışmışlardır. Böylece başta Mekke ve Medine olmak üzere nerdeyse Arap Yarımadasının tamamı İslam ile tanışmanın yanında Müslümanlar eliyle oluşturulan birliğe dâhil olmuşlardır. Bunun yanında bizzat ulaşamadıkları dünyanın başka yerlerinde yaşayan topluluklara da "Davet Mektupları" ile de olsa İslam nimetini ulaştırabilmek için gayret etmişlerdir. Bütün bunların yanında, belki bir o kadar önemli olan husus da, bu İlahi Nimet'i bütün dünyaya ulaştırma azim ve kararlılığında olan bir nesil bırakmışlardır. 


\section{Kaynakça}

Ahmed b. Hanbel, (281/855). (ts.). Müsned I-V. Beyrut.

Apak, A. (2011). Ana hatlarlyla İslam tarihi 1 (Hz. Muhammed (SAV)dönemi). İstanbul: Ensar Yayınları.

Belâzûrî, (279/892). (1963). Ensâbu'l-Eşrâf. Jerusalem.

Buharî, (256/870). (2002). Sahihu'l- Buhârî. Beyrut.

Demircan, A. (2009). Kabile topluluklarından akide toplumuna. İstanbul: Beyan Yayınları.

Demircan, A. (2013). Siyasetin kültürel ve sosyal hayattaki yansımaları bağlamında "Ensâr ve Muhacir" kavramları. ANEMON Muş Alparslan Üniversitesi Sosyal Bilimler Dergisi, 1(1), 7 16.

Demirkent, I. (1992). Bizans. Türkiye diyanet vakfi İslâm ansiklopedisi içinde (VI/230-244). İstanbul: TDV Yayınları.

Duri, A. (1991). İlk dönem İslam tarihi. (H. Yücesoy, Çev.). İstanbul: Endülüs Yay.

Ebû Dâvud, (275/888). (ts.). Sünenü Ebî Dâvûd. Riyad: Mektebetü'l- Meârif.

Hamidullah, M. (1991). İslam Peygamberi (Tuğ S. Çev.). İstanbul:İrfan Yayımcılık ve Ticaret.

Hamidullah, M. (1992). İslam müesseselerine giriş. İstanbul: Beyan Yayınları.

İbn Abdilberr, (463/1071) I.-V. (ts.). el-ístiâb fì ma'rifeti'l-ashâb. Kahire: Dâru Nehdati Misr.

İbn Hişam, (öl. 218/833). (1992). es-Sîretü’n-Nebeviyye. Beyrut: Dâru'l-Fikr.

İbn İshâk, Ebû Bekir b. Muhammed (151/768). (1981). Sîretü İbn İshâk. Konya.

İbn Kuteybe, (276/889). (1967). el-İmâme ve's- siyâse I-II. Kahire.

İbn Manzûr, (öl. 711/1311. (ts.). Lisânu'l-Arab. Beyrut: Dâru Sâdır.

İbn Sa'd, (230/845). (ts.). Tabakâtu’l-Kübrâ I-VIII. Beyrut: Dâru Sadr.

Kallek, C. (1992). Biat. Türkiye diyanet vakfi İslâm ansiklopedisi içinde VI/120-124. İstanbul: TDV Yayınları.

Kapar, M. A. (1998). İslamın ilk döneminde bey'at ve seçim sistemi. İstanbul: Beyan Yayınları.

Kutluer, İ. (2003). Medeniyet. Türkiye diyanet vakfi İslâm ansiklopedisi içinde XXVIII/296-297. İstanbul: TDV Yayınları.

Naskali, E. (2009). Sasaniler. Türkiye diyanet vakfi İslâm ansiklopedisi içinde, XXXVI/174-176. İstanbul: TDV Yayınları.

Önkal, A. (1998). Hazrec. Türkiye diyanet vakfi İslâm ansiklopedisi içinde XVII,. 143-144. İstanbul: TDV Yayınları.

Özdemir, M. (2005). Moriskolar. Türkiye diyanet vakfı İslâm ansiklopedisi içinde XXX/288-291, İstanbul: TDV Yayınları.

Özkan, M. (2016). Medine Vesikası. Türkiye diyanet vakfi İslâm ansiklopedisi içinde EK II/153154. İstanbul: TDV Yayınları.

Taberi, (310/922). (1968). Câmiu'l-Kur'ân an te'vîli âyi 'l-Kur'ân I-XXX. Misır.

Uslu, R. (1998). Hums. Türkiye diyanet vakfi İslâm ansiklopedisi içinde XVIII/364-365. İstanbul: TDV Yayınları.

Vâkıdî, (207/823). (1990). Kitabu'r-Ridde. (Yahya el-Cebûrî, Ed.). Beyrut. 
Yaman, A. (2013). Zimmî. Türkiye diyanet vakfi İslâm ansiklopedisi içinde XXXXIV/434-438. İstanbul: TDV Yayınları.

\section{ETİK ve BİLIMSEL İLKELER SORUMLULUK BEYANI}

$\mathrm{Bu}$ çalışmanın tüm hazırlanma süreçlerinde etik kurallara ve bilimsel atıf gösterme ilkelerine riayet edildiğini yazar(lar) beyan eder. Aksi bir durumun tespiti halinde Afyon Kocatepe Üniversitesi Sosyal Bilimler Dergisi'nin hiçbir sorumluluğu olmayıp, tüm sorumluluk makale yazarlarına aittir. 